\title{
Analisis Kesesuaian Perairan untuk Keramba Jaring Apung di Kecamatan Sirah Pulau Padang Kabupaten Ogan Komering Ilir Provinsi Sumatera Selatan
}

\author{
The Analysis of Water Suitability for Floating Net Sprouts in Sirah Pulau Padang, Ogan \\ Komering Ilir District, South Sumatra Province \\ Rangga Bayu Kusuma Haris ${ }^{1,2 *}$, Indah Anggraini Yusanti ${ }^{3}$ \\ ${ }^{1}$ Program Studi Budidaya Perikanan, Fakultas Perikanan, Universitas PGRI Palembang, \\ Sumatera Selatan 30116 \\ ${ }^{2}$ Politeknik Kelautan dan Perikanan Dumai, Kota Dumai, Riau 28826 \\ ${ }^{3}$ Program Studi Ilmu Perikanan, Fakultas Perikanan, Universitas PGRI Palembang, \\ Sumatera Selatan 30116 \\ ${ }^{*}$ Penulis untuk korespondensi: rangga.undip@yahoo.com
}

\begin{abstract}
The purpose of this study is to analyze the level of water suitability of the floating net sprouts in sirah pulau padang, ogan komering river, Serdang Menang Village, OKI South Sumatra Regency based on water physical and chemical parameters. This study was conducted on July - August 2018 at the Komering River, Ulak Jermun village, Terusan Menang Village, and Mangun Jaya Village, OKI District, South Sumatra. The data of sampling was divided into 3 stations, they were; station 1 was Ulak Jermun Village $\left(3^{\circ}\right.$ $18 ' 45.48$ "LS and $104^{\circ}$ 53'5.32" BT), station 2 was Terusan Menang Village ( ${ }^{\circ}{ }^{\circ} 7^{\prime} 14.13$ "LS and $104^{\circ} 52^{\prime} 46.78$ "BT), and station 3 was Mangun Jaya village ( $3^{\circ} 18^{\prime} 14.92 "$ LS and $104^{\circ} 52^{\prime} 59.48$ "BT). The data of Samples were tested at the chemical laboratory in Palembang Public Water Fisheries and Extension Research Institute directly. The results of the study was for Station 1, Station 2, and Station 3 with a value was $48 \%$ with a good feasibility information. The results of measurements of water quality parameters, the $\mathrm{pH}$ was about 6.6 - 6.7, temperature was about from 24., 53 - 26.93oC, DO $3.93-4.36 \mathrm{mg} / 1$, ammonia was about $0.78-0.16 \mathrm{mg} / \mathrm{l}$, water brightness was about from $34.67-43.33 \mathrm{~cm}$, $\mathrm{CO} 24.53-5.03 \mathrm{mg} / 1$, depth $2.36-2.47 \mathrm{~m}$, current velocity was about $0.38-0.44 \mathrm{~m} / \mathrm{s}$, nitrate was about $0.37-0.439 \mathrm{mg} / 1$, phosphate was about $0.009-0.225 \mathrm{mg} / 1$ and the bottom substrate of water was mud.
\end{abstract}

Keywords: komering River, Floating Net sprouts, Water Suitability

\section{ABSTRAK}

Penelitian ini bertujuan untuk menganalisis tingkat kesesuaian perairan keramba jaring apung (KJA) di sungai Komering Desa Serdang Menang Kabupaten OKI Sumatera Selatan berdasarkan parameter fisika dan kimia air. Penelitian ini dilaksanakan pada bulan Juli - Agustus 2018 di Sungai Komering, desa Ulak Jermun, Desa Terusan Menang, dan Desa Mangun Jaya Kab OKI Sumatera Selatan. Pengambilan sampel akan dibagi dalam 3

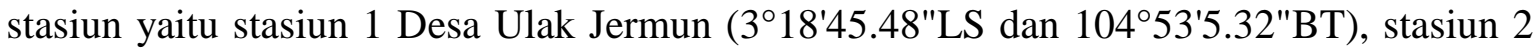
Desa Terusan Menang ( $3^{\circ} 17^{\prime} 14.13^{\prime \prime L S}$ dan 104'52'46.78"BT), dan stasiun 3 Desa Mangun Jaya (3¹8'14.92"LS dan 104'52'59.48"BT). Sampel diuji secara langsung dan di laboratorium kimia Balai Riset Perikanan Perairan Umum Dan Penyuluhan Perikanan 
Palembang. Dari hasil penelitian Analisis Kesesuaian Lahan Keramba Jaring Apung Di Sungai Komering Desa Serdang Menang Kabupaten OKI Sumatera Selatan bahwa untuk Stasiun 1, Stasiun 2, dan Stasiun 3 dengan nilai $48 \%$ dengan keterangan kelayakan baik. Dari hasil pengukuran parameter kualitas air didapat $\mathrm{pH}$ kisaran $6.6-6.7$, suhu berkisar $24 ., 53-26.93^{\circ} \mathrm{C}$, DO $3.93-4.36 \mathrm{mg} / \mathrm{l}$, ammonia $0.78-0,16 \mathrm{mg} / \mathrm{l}$, kecerahan perairan berkisar $34.67-43.33 \mathrm{~cm}, \mathrm{CO}_{2} 4.53-5.03 \mathrm{mg} / \mathrm{l}$, kedalaman $2.36-2.47 \mathrm{~m}$, kecepatan arus $0.38-0.44 \mathrm{~m} / \mathrm{s}$, nitrat $0.37-0.439 \mathrm{mg} / \mathrm{l}$, fosfat $0.009-0.225 \mathrm{mg} / \mathrm{l}$ dan subtrat dasar perairan adalah lumpur.

Kata kunci: sungai Komering, Keramba Jaring Apung, Kesesuaian Perairan

\section{PENDAHULUAN}

Kualitas lingkungan perairan sangat berkaitan erat dengan fenomena alam dan jenis serta intensitas kegiatan manusia yang ada, baik di lingkungan daratan sekitar perairan maupun di perairan itu sendiri, baik dari bidang perikanan maupun dari non bidang perikanan (Wiadnyana, et.al., 2011). Kecamatan Sirah Pulau Padang memiliki luas wilayah $149,08 \mathrm{~km}^{2}$ dengan jumlah penduduk 41.709 jiwa merupakan salah satu wilayah di Kabupaten Ogan Komering Ilir Provinsi Sumatera Selatan memiliki potensi perairan umum daratan yang luas. Kabupaten Ogan Komering Ilir dialiri oleh beberapa sungai besar yaitu sungai Komering yang mengalir mulai dari Kecamatan Tanjung Lubuk, Pedamaran, Kayuagung, Sirah Pulau Padang dan Kecamatan Jejawi serta bermuara di Sungai Musi di Kota Palembang, Sungai Mesuji mengalir dari Kecamatan Mesuji sampai Kecamatan Sungai Menang yang merupakan perbatasan Kabupaten OKI dengan Kabupaten Tulang Bawang Provinsi Lampung (Badan Pusat Statistik Ogan Komering Ilir, 2015).

Pemanfaatan sumberdaya perlu mempertimbangkan kemampuan daya dukung wilayah setempat (Haris et al, 2014). Menurut Hasnawi dan Mustafa (2010), perbedaan kombinasi penyusun lingkungan fisik lahan akan memberikan perbedaan lahan dan cara pengelolaan lahan yang berbeda. Pemeliharaan ikan dalam keramba di sungai Komering di Kecamatan Sirah Pulau Padang jika tidak dilaksanakan dengan prinsip sustainability akan menimbulkan dampak penurunan mutu perairan yang digunakan dan tidak dapat dimanfaatkan secara berkelanjutan. Perubahan kualitas perairan dapat diketahui dari indikator kimia, fisika, maupun biologis. Indikator kimiawi dapat diketahui melalui penilaian kualitas perairan yang meliputi antara lain $\mathrm{pH}$-air, oksigen terlarut, karbondioksida. Indikator fisika dapat diketahui melalui parameter suhu air, kecerahan dan arus air (Samuel dan Adjie, 2008). Tujuan dari penelitian ini adalah untuk menganalisis tingkat kesesuaian lahan keramba jaring apung (KJA) di sungai Komering Desa Serdang Menang kabupaten OKI Sumatera Selatan.

\section{BAHAN DAN METODE}

\section{Waktu dan Tempat}

Penelitian ini dilakukan di sekitar perairan desa Ulak Jermun, Desa Mangun Jaya dan Desa Terusan Menang kecamatan Sirah Pulau Padang Kabupaten Ogan Komering Ilir Sumatera Selatan yang banyak budidaya ikan dalam keramba. Pengambilan contoh dilakukan pada bulan Juli sampai dengan Agustus 2018.

\section{Metoda Pengumpulan Data}

Pengamatan secara langsung meliputi: suhu, kecerahan, kedalaman, kecepatan arus, kandungan oksigen, subtrat dasar perairan, dan $\mathrm{pH}$. Sedangkan parameter ammonia, nitrat, $\mathrm{CO}_{2}$, dan fosfat di analisis di laboratorium di Balai Riset Perikanan Perikanan Umum dan Penyuluhan Perikanan Palembang. Dalam penelitian ini yang menjadi sumber data 
sekunder adalah literatur,artikel, jurnal serta situs di internet yang berkenaan dengan penelitian yang dilakukan.

\section{Analisis Data}

Parameter penentuan kelayakan diberi nilai 1 - 5 (Sangat kurang, kurang, cukup, baik dan sangat baik). Nilai - nilai tersebut dibentuk atas dasar rentang minimum dan maksimum setiap parameter. Setiap parameter diberi bobot sesuai peranannya bagi kelayakan budidaya perikanan dengan diberi nilai $1-3$. Nilai kelayakan ditetapkan berdasarkan rumus berikut : (Praptokardyo dan Wellem, 2008).

\section{KK = Ai X Bi}

Keterangan :

$\mathrm{KK}=$ Kelayakan Kawasan

$\mathrm{Ai}=$ Nilai kualitas parameter

$\mathrm{Bi}=$ Peranan bobot

Total nilai kesesuaian actual dibagi total nilai kesesuaian maksimal untuk menentukan tingkat kelayakan kawasan budidaya perikanan yang dapat dinyatakan (Praptokardyo dan Wellem, 2008) :

$$
\begin{aligned}
& 80-100 \%=\text { Kelayakan sangat baik } \\
& \text { (Excelent) } \\
& 60-79 \%=\text { Kelayakan sangat baik } \\
& 45-59 \%=\text { Kelayakan baik } \\
& <40 \%=\text { Kelayakan sangat }
\end{aligned}
$$

Wilayah pengembangan perikanan budidaya perikanan system KJA perlu diidentifikasi dan perlu adanya evaluasi beberapa kawasan calon pengembangan budidaya perikanan system KJA yang dapat dilakukan. Kegiatan evaluasi perlu dilakukan atas kesesuaian biofisik, smberdaya dan lingkungan bagi produksi budidaya perikanan system KJA). Kesesuaian lahan didasarkan pada parameter biofisik yang dievaluasi dan diberi nilai atas dasar kriteria:

$$
\text { S1 = Sangat sesuai }
$$

$$
\begin{aligned}
\text { S2 } & =\text { Sesuai } \\
\text { S3 } & =\text { Sesuai syarat } \\
\mathrm{N} & =\text { Tidak sesuai }
\end{aligned}
$$

Setiap kriteria tersebut diberi nilai berturut - turut :

$\mathrm{S} 1=5$

$\mathrm{S} 2=4$

$\mathrm{S} 3=3$

$\mathrm{N} 1=2$

$\mathrm{N} 2=1$

Parameter kesesuaian lahan perlu diberikan nilai peranannya bagi fungsi produksi dengan pembobotan 3, 2, dan 1 sesuai dengan peranan parameter yang bersangkutan. Kesesuaian lahan bagi keramba jaring apung (KJA) ditentukan oleh parameter kualitas air ( $\mathrm{pH}, \mathrm{Suhu}, \mathrm{DO}$, Arus air, Amonia, Nitrat, $\mathrm{CO}_{2}$, Subtrat Dasar, Kedalaman, Kecerahan) dengan kriteria S3, S2, S1, N1, dan N2 dengan nilai berturut - turut 3, 4, 5, 2, dan 1. Setiap parameter diberikan bobot peranannya bagi pengembangan usaha antara $1-3$.

\section{HASIL DAN PEMBAHASAN}

\section{Analisa Kesesuaian Lahan}

Analisa kesesuaian wilayah diperlukan untuk mengetahui wilayah potensial perairan bagi kegiatan budidaya perikanan pada sistem KJA setiap stasiun yang diamati. Setiap parameter memiliki bobot dan skor yang penentuannya disesuaikan dengan studi literatur dan besar pengaruhnya terhadap kegiatan budidaya perikanan pada sistem KJA pada stasiun yang diamati sebelum dimasukkan ke dalam tabel.

Berdasarkan hasil pembobotan atau scorring gabungan data kualitas air, diketahui bahwa di sungai Komering Desa Serdang Menang kabupaten OKI Sumatera Selatan masih cocok dijadikan sebagai tempat pembudidayaan melalui sistem keramba jaring apung. Hasil penghitungan kesesuaian lahan dengan metode pembobotan menunjukkan kesesuaian lahan yang ada di sungai Komering Desa Serdang 
Menang kabupaten OKI Sumatera Selatan tergolong dalam kelayakan baik yaitu dengan nilai kelayakan 48. Hal ini dapat dilihat dari setiap stasiun masih kelayakan baik di lokasi tersebut tanpa adanya stasiun tidak sesuai. Hal ini dikarenakan hamper semua parameter yang diukur masih berada dalam batasan normal untuk menunjang kegiatan budidaya. Pengetahuan akan kualitas lahan merupakan salah satu informasi dasar yang diperlukan bagi memanfaatkan lahan untuk budidaya system KJA. Guna untuk mengetahui kualitas lahan diperlukan pengukuran secara langsung di lapangan maupun dari data sekunder (pengamatan dari pihak lain) selanjutnya data tersebut dianalisis, sehingga menghasilkan informasi yang akurat untuk keperluan pengembangan budidaya system KJA.

Tabel 1. Kesesuaian lahan

\begin{tabular}{|c|c|c|c|c|c|c|}
\hline \multirow[t]{2}{*}{ Kualitas/Karateristik Lahan } & \multicolumn{6}{|c|}{ Kesesuaian } \\
\hline & S1 & S2 & S3 & N1 & $\mathrm{N} 2$ & Bobot \\
\hline \multirow[t]{2}{*}{ 1. $\operatorname{Suhu}\left({ }^{\circ} \mathrm{C}\right)$} & $28-29$ & $27-28 / 29$ & $25-27 /$ & $<25:>$ & & 1 \\
\hline & & -30 & $30-31$ & 31 & & \\
\hline \multirow[t]{2}{*}{ 2. Kecerahan $(\mathrm{cm})$} & $25-30$ & $30-40$ & $35-50$ & $>50$ & & 1 \\
\hline & & $20-25$ & & & & \\
\hline 3. Kedalaman $(\mathrm{cm})$ & $1-1,5$ & $1,5-2$ & $2-2,5$ & $>2,5$ & & 1 \\
\hline 4. Kecepatan Arus m/menit & $0,1-1$ & $1-1,5$ & $1,5-2,5$ & $>2,5$ & & 1 \\
\hline 5. Substrat Dasar Perairan & $\begin{array}{l}\text { Pasir } \\
\text { berlumpur }\end{array}$ & Lumpur & $\begin{array}{l}\text { Karang } \\
\text { berpasir }\end{array}$ & Karang & - & 1 \\
\hline \multirow[t]{2}{*}{ 6. $\mathrm{pH}$} & $6,5-7,5$ & $5,5-6,5$ & $4-5,5 /$ & $<4:>9$ & & 1 \\
\hline & & $17,5-8$ & $8-9$ & & & \\
\hline 7. $\mathrm{DO}$ & $>5$ & $3-5$ & $1-3$ & $<1$ & & 1 \\
\hline 8. $\mathrm{CO}_{2}$ & $<5$ & $5-6$ & $6-7,5$ & $>7,5$ & & 1 \\
\hline 9. Nitrat $\left(\mathrm{NO}_{3}\right)$ & $0,5-1$ & $1-1,5$ & $1,5-2$ & $>2$ & & 1 \\
\hline 10. Ammonia & $<0.3$ & $0.3-0.4$ & $0.4-0.5$ & $0.5-1$ & $>1$ & 1 \\
\hline 11.Fosfat & $<1$ & $1-1,5$ & $1,5-2$ & $>2$ & & 1 \\
\hline
\end{tabular}

Tabel 2. Pengamatan kualitas air

\begin{tabular}{|c|c|c|c|c|c|c|}
\hline Parameter & $\begin{array}{c}\text { Desa } \\
\text { Ulak } \\
\text { Jermun }\end{array}$ & Kesesuaian & $\begin{array}{c}\text { Desa } \\
\text { Terusan } \\
\text { Menang }\end{array}$ & Kesesuaian & $\begin{array}{c}\text { Desa } \\
\text { Mangun } \\
\text { Jaya }\end{array}$ & Kesesuaian \\
\hline $\mathrm{pH}$ & 6.7 & S1 & 6.6 & S1 & 6.6 & S1 \\
\hline Suhu $\left({ }^{0} \mathrm{C}\right)$ & 26.93 & $\mathrm{~S} 1$ & 25.03 & S1 & 24.53 & $\mathrm{~S} 2$ \\
\hline $\mathrm{DO}(\mathrm{mg} / \mathrm{l})$ & 3.93 & $\mathrm{~S} 2$ & 4.27 & $\mathrm{~S} 2$ & 4.36 & $\mathrm{~S} 2$ \\
\hline Kecerahan $(\mathrm{cm})$ & 42.67 & S3 & 43.33 & S3 & 34.67 & $\mathrm{~S} 2$ \\
\hline $\mathrm{CO}_{2}(\mathrm{mg} / \mathrm{l})$ & 4.83 & $\mathrm{~S} 2$ & 4.53 & $\mathrm{~S} 2$ & 5.03 & $\mathrm{~S} 2$ \\
\hline Kedalaman (m) & 2.41 & S3 & 2.26 & $\mathrm{~S} 3$ & 2.47 & $\mathrm{~S} 3$ \\
\hline Kecepatan Arus & 0.41 & $\mathrm{~S} 1$ & 0.38 & S1 & 0.44 & S1 \\
\hline Ammonia (mg/l) & 0.0813 & $\mathrm{~S} 1$ & 0.078 & S1 & 0.16 & S1 \\
\hline Nitrat $\left(\mathrm{NO}_{3}\right)(\mathrm{mg} / \mathrm{l})$ & 0,439 & $\mathrm{~S} 1$ & 0.38 & S1 & 0.37 & S1 \\
\hline Fosfat (mg/l) & 0.225 & $\mathrm{~S} 1$ & 0.009 & $\mathrm{~S} 1$ & 0.011 & $\mathrm{~S} 1$ \\
\hline $\begin{array}{l}\text { Subtrat Dasar } \\
\text { Perairan }\end{array}$ & Lumpur & $\mathrm{S} 2$ & Lumpur & $\mathrm{S} 2$ & Lumpur & $\mathrm{S} 2$ \\
\hline
\end{tabular}

Sumber: Data Penelitian, 2018. 
Untuk Melihat analisa kesesuaian lahan (Tabel 3).

Tabel 3. Analisa kesesuaian lahan

\begin{tabular}{|c|c|c|}
\hline Lokasi & Nilai & Keterangan \\
\hline Stasiun 1 & 48 & Kelayakan Baik \\
\hline Stasiun 2 & 48 & Kelayakan Baik \\
\hline Stasiun 3 & 48 & Kelayakan Baik \\
\hline
\end{tabular}

Sumber : Data Penelitian, 2018

Pada kegiatan ini, peneliti tidak melakukan penelitian terhadap sedimen dan unsur hara. Jika dilihat dari sedimen dan kandungan unsur haranya, tentu saja bisa terdapat stasiun tidak sesuai karena sungai Komering Desa Serdang Menang kabupaten OKI Sumatera Selatan merupakan sungai yang masih dipengaruhi oleh pasang surut. Kesesuaian ini akan dapat terus berlangsung apabila nantinya para pembudidaya tetap memperhatikan dan mengontrol kualitas air perairan, memberi pakan tidak secara sembarangan melainkan dengan metode FCR sehingga tidak ada pakan yang terbuang sia-sia serta selalu membersihkan kotoran dan organisme yang menempel pada tali keramba.

Kesinambungan dan optimalisasi perikanan budidaya ikan sistem KJA tergantung dari daya dukung perairan, yang ditinjau dari: 1). Daya dukung terhadap dampak penambahan hara dari proses budidaya yang tidak menimbulkan proses eutrofikasi dan penurunan kualitas air yang dapat mengganggu aktivitas lainnya dengan kebutuhan kualitas air yang tinggi; dan 2).

Daya dukung terhadap tetap tersedianya cadangan oksigen dalam menerima dan mendegradasi limbah organik dari sisa pakan dan feses. Sementara itu potensi pengembangan perikanan budidaya KJA dari suatu perairan multifungsi, selain dibatasi oleh faktor dayad ukung perairan, juga dibatasi oleh fungsi dan pemanfaatan lain. Selain factor faktor tersebut, daya dukung terutama akan sangat ditentukan oleh karakteristik fisik lingkungan perairan.

\section{Pengamatan Kualitas Air}

Hasil pengamatan kondisi perairan di sungai Komering pada saat surut dan pasang menunjukan nilai yang berfluktuasi. Pengamatan dilakukan sebanyak tiga kali dengan titik stasiun yang telah ditentukan yaitu area Desa Ulak Jermun (stasiun 1), Desa Terusan Menang (stasiun 2), dan Desa Mangun Jaya (stasiun 3). Perubahan kualitas air dipengaruhi oleh perubahan muka air. Dalam proses tersebut juga akan terjadi proses pelarutan mineral-mineral dari tanah yang sebelumnya kering, diikuti oleh proses pembusukan tumbuh-tumbuhan yang hidup di lahan surutan tersebut. Beberapa parameter kualitas air seperti suhu, $\mathrm{pH}$, kecerahan, kedalaman, kecepatan arus, DO, $\mathrm{CO}_{2}, \mathrm{NH}_{3}, \mathrm{NO}_{3}$, dan fosfat menunjukkan perubahan sebagai akibat dari perubahan muka air (Tabel 4).

\section{Derajat Keasaman (pH)}

Hasil pengukuran $\mathrm{pH}$ pengambilan sampel pada stasiun 1, 2 dan 3 berkisar 6.6 - 6.7 secara umum nilai $\mathrm{pH}$ masih normal. Menurut Pescod (1973), batas toleransi organisme terhadap $\mathrm{pH}$ bervariasi dan dipengaruhi oleh banyak faktor antara lain suhu, oksigen terlarut, alkalinitas dan adanya berbagai anion dan kation. Pada $\mathrm{pH}$ rendah (keasaman tinggi) kandungan oksigen terlarut akan berkurang. Akibatnya, konsumsi oksigen menurun, aktivitas pernafasan naik dan selera makan akan berkurang. Pengaruh perairan asam $(\mathrm{pH}$ rendah) akan kurang produktif untuk budidaya system KJA karena pertumbuhan ikan akan terhambat dan ikan rentan terkena bakteri dan parasit, bahkan bisa terjadinya kematian pada ikan (Effendi, 2003). 
Tabel 4. Hasil pengukuran kualitas air pada 3 stasiun

\begin{tabular}{|c|c|c|c|}
\hline Parameter & $\begin{array}{c}\text { Stasiun } 1 \\
\text { Desa Ulak Jermun }\end{array}$ & $\begin{array}{c}\text { Stasiun } 2 \\
\text { Desa Terusan Menang }\end{array}$ & $\begin{array}{c}\text { Stasiun } 3 \\
\text { Desa Mangun Jaya }\end{array}$ \\
\hline $\mathrm{pH}$ & 6.7 & 6.6 & 6.6 \\
\hline Suhu $\left({ }^{0} \mathrm{C}\right)$ & 26.93 & 25.03 & 24.53 \\
\hline DO (mg/l) & 3.93 & 4.27 & 4.36 \\
\hline Kecerahan $(\mathrm{cm})$ & 42.67 & 43.33 & 34.67 \\
\hline $\mathrm{COD}(\mathrm{mg} / \mathrm{l})$ & 4.83 & 4.53 & 5.03 \\
\hline Kedalaman (m) & 2.41 & 2.26 & 2.47 \\
\hline Kecepatan Arus (m/s) & 0.41 & 0.38 & 0.44 \\
\hline Ammonia $\left(\mathrm{NH}_{3}\right)(\mathrm{mg} / \mathrm{l})$ & 0.0813 & 0.078 & 0.16 \\
\hline Nitrat $\left(\mathrm{NO}_{3}\right)(\mathrm{mg} / \mathrm{l})$ & 0,439 & 0.38 & 0.37 \\
\hline Fosfat (mg/l) & 0.225 & 0.009 & 0.011 \\
\hline Subtrat Dasar Perairan & Lumpur & Lumpur & Lumpur \\
\hline
\end{tabular}

\section{Suhu}

Data pengukuran suhu air di Desa Ulak Jermun (stasiun 1), Desa Terusan Menang (stasiun 2), dan Desa Mangun Jaya (stasiun 3) pada pengambilan sampel kualitas air berkisar $24.53-26.93{ }^{\circ} \mathrm{C}$. Menurut Hutabarat (2010) bahwa tingginya suhu disuatu perairan bisa disebabkan oleh tingginya cahaya matahari dan adanya pencampuran air, serta oleh faktor aktifitas yang ada diperairan tersebut. Suhu yang didapat dari hasil penelitian berkisar antara 24.53 - $26.93{ }^{\circ} \mathrm{C}$ dan termasuk ke dalam suhu normal yang dibutuhkan ikan untuk dapat berkembang dan bertahan hidup.

\section{Oksigen Terlarut (DO)}

DO (Dissolved Oxygen) atau oksigen terlarut merupakan zat yang paling penting dalam sistem kehidupan di perairan karena berperan penting dalam proses metabolisme serta respirasi. Dari penelitian yang dilakukan, didapati oksigen terlarut di Desa Ulak Jermun (stasiun 1), Desa Terusan Menang (stasiun 2), dan Desa Mangun Jaya (stasiun 3) berkisar antara 3.93-4.36 mg/L sehingga dapat disimpulkan jika oksigen terlarut di perairan tersebut dapat mendukung kegiatan KJA. DO dan suhu sangat berkaitan, semakin tinggi suhu maka DO akan semakin rendah. Menurut Sastrawijaya (2000) menyatakan bahwa kehidupan organisme akuatik berjalan dengan baik apabila kandungan oksigen terlarutnya minimal $5 \mathrm{mg} / \mathrm{l}$. Mundeng, dkk., (2013) biota air membutuhkan oksigen guna pembakaran bahan bakarnya (makanan) untuk menghasilkan aktifitas, seperti aktifitas berenang, pertumbuhan, reproduksi, dan sebaliknya.

\section{Kecerahan}

Kecerahan adalah suatu kondisi yang menunjukkan kemampuan cahaya untuk menembus lapisan air pada kedalaman tertentu. Kecerahan perairan sangat dipengaruhi oleh keberadaan padatan tersuspensi, zat - zat terlarut, partikel partikel dan warna air. Tingkat kecerahan memiliki kaitan erat dengan fotosintesis. Kecerahan berperan dalam menyediakan sinar matahari yang diperlukan oleh tumbuhan air dan fitoplankton dalam melakukan fotosintesis. Hasil pengamatan kecerahan pada pengambilan sampel saat air sungai surut di stasiun 1,2 dan 3 berkisar 34.67 - $43.33 \mathrm{~cm}$. Dari hasil pengamatan kecerahan pada Sungai Komering di Desa Ulak Jermun (stasiun 1), Desa Terusan Menang (stasiun 2), dan Desa 
Mangun Jaya (stasiun 3) secara umum tingkat kecerahan tersebut baik untuk pengembangan budidaya system KJA. Menurut Sumich (1992) dalam Asmara (2005) bahwa semakin dalam secchidisk semakin dalam penetrasi cahaya kedalam air, yang selanjutnya akan meningkatkan ketebalan lapisan air yang produktif. Tebalnya lapisan air yang produktif memungkinkan terjadinya pemanfaatan unsur hara secara kontinyu oleh produsen primer.

\section{Karbondioksida $\left(\mathrm{CO}_{2}\right)$}

\section{Ketersediaan}

karbondioksida

terlarut dalam air dapat bersumber dari air tanah, dekomposisi zat organik, respirasi organisme air, senyawa kimia dalam air maupun dari udara namun dalam jumlah yang sedikit. Hasil pengukuran $\mathrm{CO}_{2}$ pada pengambilan sampel saat air sungai surut dengan rata-rata $6.99 \mathrm{mg} / \mathrm{L}$ dan pada pengambilan sampel saat air sungai pasang rata-rata $7.03 \mathrm{mg} / \mathrm{L}$, terjadi peningkatan. Menurut Ellis dalam Boyd (1979), kandungan karbondioksida yang baik untuk menunjang kehidupan ikan adalah kurang dari 5,0 mg/l dan ikan dapat mentolerir kandungan karbondioksida lebih dari 10 $\mathrm{mg} / \mathrm{l}$ apabila kandungan oksigennya tinggi.

Dari hasil pengamatan untuk karbondioksida $\left(\mathrm{CO}_{2}\right)$ di Sungai Komering desa Serdang Menang masih sesuai untuk budidaya perikanan system KJA dikarenakan tingginya karbondioksida yang terlarut dalam perairan tersebut, sedangkan oksigen terlarut hasil penelitian ini rendah yang merupakan keterbalikan dari hasil $\mathrm{CO}_{2}$ yang didapat.

Apabila karbondioksida $\left(\mathrm{CO}_{2}\right)$ yang dihasilkan dari respirasi makin banyak, reaksi bergerak kekanan dan secara bertahap melepaskan ion $\mathrm{H}^{+}$yang menyebabkan $\mathrm{pH}$ air turun dan reaksi sebaliknya $\mathrm{pH}$ air akan naik. Jumlah $\mathrm{CO}_{2}$ yang meningkat akan menekan aktifitas pernafasan ikan dan menghambat peningkatan oksigen oleh hemoglobin sehingga menjadi sumber stress bagi ikan. Ketersediaan karbondioksida adalah sumber utama untuk fotosintesis dan pada banyak cara menunjukkan keterbalikan dengan oksigen. Semakin menipisnya intensitas cahaya matahari, kandungan karbondioksida dalam air semakin besar. Sedangkan semakin banyaknya intensitas cahaya matahari, kandungan karbondioksida menipis kembali. Meskipun suhu dan $\mathrm{pH}$ merupakan faktor dalam regulasi konsentrasi oksigen dan karbondioksida, tetapi hal ini juga tergantung pada fotosintesis tanaman, respirasi dari semua organisme, aerasi air, keberadaan gas-gas lainnya dan oksidasi kimia yang mungkin terjadi.

\section{Kedalaman Air Sungai}

Kedalaman lokasi KJA yang dipilih tidak boleh terlalu dangkal dan terlalu dalam. Hasil rata - rata pengukuran kedalaman pada pengambilan sampel berkisar antara $2.26 \mathrm{~m}-2.47 \mathrm{~m}$. Dalam WWF-Indonesia (Irwan dkk, 2015), ketinggian air pada saat kemarau atau surut minimal $1 \mathrm{~m}$ untuk KJT sedangkan untuk KJA jarak minimal antara dasar sungai / danau / waduk dengan dasar waring/jaring adalah $1 \mathrm{~m}$, sehingga didapat kedalaman untuk pengembangan budidaya perikanan air tawar seperti ikan patin masih bisa dilakukan di Desa Ulak Jermun (stasiun 1), Desa Terusan Menang (stasiun 2), dan Desa Mangun Jaya (stasiun 3).

Menurut Sari (2011) menyatakan bahwa pada perairan dengan kedalaman terlalu dekat dengan dasar sehingga rentan terhadap penumpukan kotoran dari sisa pakan dan hasil metabolisme ikan. Semakin dalam dasar permukaan air di kolam atau perairan tersebut, maka semakin luas ruang gerak ikan. Salah satu pertimbangan dalam menentukan kedalaman suatu kolam atau perairan, yaitu kemampuan sinar matahari untuk menembus ke dasar kolam atau suatu perairan (Susanto, 1986).

\section{Kecepatan Arus Sungai}

Hasil rata-rata pengukuran kecepatan arus pada pengambilan sampel saat air sungai surut dan pasang berkisar 
$0,38-0,44 \mathrm{~m} / \mathrm{s}$. Hal ini menunjukan bahwa kecepatan arus di lokasi penelitian relatif kencang, sebagaimana dalam WWFIndonesia (Irwan dkk, 2015), penempatan KJA sebaiknya ditempatkan diperairan dengan pergerakan air cukup baik, kecepatan arus berkisar $0,5 \mathrm{~m} / \mathrm{menit}$ untuk KJT dan untuk KJA berkisar $1 \mathrm{~m} /$ menit, sehingga untuk pengembangan budidaya perikanan system KJA layak untuk dilakukan di Desa Ulak Jermun (stasiun 1), Desa Terusan Menang (stasiun 2), dan Desa Mangun Jaya (stasiun 3). Menurut Effendi (2003) bahwa perairan lotik dicirikan oleh arus yang searah dan relatif kencang, dengan kecepatan arus berkisar antara 0,1 - 1,0 m/detik, serta sangat dipengaruhi oleh waktu, iklim, dan pola drainase. Kecepatan arus mempunyai pengaruh yang besar terhadap distribusi atau penyebaran organisme termasuk benthos. Selain itu kecepatan arus merupakan sarana transport yang baik untuk makanan maupun oksigen bagi organisme.

Menurut Odum (1996) yang menjadi acuan oleh Johan dan Ediwarman (2011) yang mengatakan bahwa kecepatan arus di sungai tergantung pada kemiringan, kekasaran, kedalaman dan kelebaran dasar perairan. arus berperan dalam sirkulasi air dan distribusi bahan terlarut maupun oksigen. Hal ini sesuai dengan pernyataan Affan (2012) yang menyatakan bahwa arus sangat berperan dalam sirkulasi air, selain pembawa bahan terlarut dan tersuspensi, arus juga mempengaruhi jumlah kelarutan oksigen dalam air. $\mathrm{Di}$ samping itu berhubungan dengan KJA, kekuatan arus dapat mengurangi organisme penempel (fouling) pada jaring sehingga desain dan konstruksi keramba harus disesuaikan dengan kecepatan arus.

\section{Ammonia $\left(\mathbf{N H}_{3}\right)$}

Amonia merupakan parameter penting dalam budidaya perikanan system KJA karena dapat dianggap sebagai satu racun paling mematikan dalam kegiatan budidaya. Amonia merupakan produk akhir metabolisme nitrogen yang bersifat racun.
Kandungan amoniak pada perairan sungai Komering di Desa Ulak Jermun (stasiun 1), Desa Terusan Menang (stasiun 2), dan Desa Mangun Jaya (stasiun 3). berkisar antara $0.078-0.16 \mathrm{mg} / \mathrm{L}$. Ammonia $\left(\mathrm{NH}_{3}\right)$ dalam air berasal dari bahan-bahan organik dan pengeluaran hasil metabolisme ikan melalui ginjal dan jaringan insang. Kemudian ammonia dalam keramba, tambak atau perairan dapat pula terbentuk sebagai hasil proses dekomposisi protein yang berasal dari sisa pakan atau plankton yang mati. Bila proses pembusukan (nitrifikasi) tidak berlangsung lancar maka terjadi pembusukan $\mathrm{NH}_{3}$ sampai pada konsentrasi yang membahayakan ikan. Menurut Boyd (1983), kandungan amoniak sudah dapat bersifat racun pada konsentrasi 0,6 - 2,0 $\mathrm{mg} / \mathrm{L}$. Daya racun amoniak akan meningkat sebanding dengan meningkatnya $\mathrm{pH}$ dan suhu.

Effendi (2003) dalam Slamet, dkk. (2013) mengemukakan bahwa amonia dapat berasal dari limbah budidaya perikanan yang berupa feses dan pakan yang tidak dimakan yang terlepas ke lingkungan perairan. Amonia bebas yang tidak terionisasi bersifat toksik terhadap biota dan toksisitas tersebut akan meningkat jika terjadi penurunan kadar oksigen terlarut. Hal ini juga didukung oleh Beveridge (1996) yang diacu oleh Ervinia (2011) menyebutkan bahwa pakan ikan yang terbuang ke perairan banyak mengandung nitrogen. Jumlah penambahan nutrien ke badan air dari keramba jaring apung tergantung pada densitas ikan dalam keramba. Hasil ekskresi ikan akan disebarkan ke kolom air oleh arus, sedangkan padatan (pakan yang tidak termakan dan feses) akan jatuh ke bawah atau dasar perairan.

\section{Nitrat $\left(\mathrm{NO}_{3}\right)$}

Hasil pengamatan parameter nitrat pada stasiun 1, 2 dan 3 pengambilan sampel berkisar $0.37-0.439 \mathrm{mg} / \mathrm{L}$. Chu dalam Wardoyo (1982) mengemukakan bahwa kisaran kadar nitrat 0,3-0,5 mg/l baik untuk pertumbuhan organisme dan $>3,5 \mathrm{mg} / \mathrm{l}$ 
dapat membahayakan perairan. Berdasarkan PP No. 82 Tahun 2001, kandungan $\mathrm{NO}_{3}$ bagi ikan yaitu $10-20 \mathrm{mg} / \mathrm{l}$. Nitrat merupakan sumber nitrogen bagi tumbuhan yang selanjutnya dikonversi menjadi protein (Effendi, 2003). Untuk kadar nitratnitrogen pada perairan alami hampir tidak pernah melebihi dari $0,1 \mathrm{mg} / \mathrm{l}$, bila kadar nitrat lebih dari $5 \mathrm{mg} / \mathrm{l}$ menggambarkan terjadinya pecemaran yang berasal dari aktifitas manusia dan tinja hewan. Kadar nitrat untuk keperluan air minum sebaiknya tidak melebihi $10 \mathrm{mg} / \mathrm{l}$ (Davis dan Cornwell dalam Effendi, 2003).

Nitrat adalah bentuk utama nitrogen di perairan alami dan merupakan nutrien utama bagi pertumbuhan tanaman dan algae. Tanaman air dan fitoplankton lebih mudah menggunakan nitrogen dalam bentuk nitrat, maka semua nitrogen baru tersedia jika telah dalam bentuk nitrat. Pembentukan nitrat sangat tergantung pada adanya oksigen dalam proses oksidasi oleh bakteri Nitrobacter yang bertugas mengubah nitrit menjadi nitrat secara aerob (Isnaini, 2011).

Konsentrasi oksigen terlarut yang sangat rendah dapat mengakibatkan terjadinya proses denitrifikasi, yaitu perubahan nitrat melalui nitrit yang akan menghantarkan nitrogen bebas yang akhirnya akan lepas ke udara atau kembali membentuk ammonium melalui proses ammonium nitrat.

Parameter nitrat sangat penting untuk mengetahui kemampuan self purification suatu perairan dan untuk mengetahui keseimbangan unsur hara di air permukaan dan tanah (HH Rump dan $\mathrm{H}$. Krist, 1992). Ditinjau dari kadar nitrat yang merupakan salah satu indikator kesuburan, maka perairan sungai Desa Ulak Jermun (stasiun 1), Desa Terusan Menang (stasiun 2), dan Desa Mangun Jaya (stasiun 3) baik untuk kegiatan budidaya perikanan system KJA yang berkisar $0.37-0.439 \mathrm{mg} / \mathrm{l}$.

\section{Fosfat $\left(\mathrm{PO}_{4}\right)$}

Fosfat merupakan nutrisi yang paling penting dalam menentukan produktivitas perairan. Keberadaan fosfat diserap oleh bakteri, phytoplankton dan makrofita. Fosfat seperti juga nitrogen dan sulfur, turut serta dalam daur geologis dunia. Dalam daur yang kecil, bahan organik yang mengandung fosfat (misalnya, sisa tumbuhan dan kotoran hewan) jadi busuk dan fosfat menjadi tersedia untuk diambil oleh akar tumbuhan dan penggabungan hasil menjadi bahan organik. Setelah melalui rantai makanan, sekali lagi melalui pengurai dan daur itu tertutup.

Air mengikis fosfat tidak hanya dari batuan yang mengandung fosfat tetapi juga dari tanah. Kandungan rata-rata nilai fosfat untuk dari pengambilan sampel berkisar $0.009-0.225 \mathrm{mg} / \mathrm{L}$ di Desa Ulak Jermun (stasiun 1), Desa Terusan Menang (stasiun 2), dan Desa Mangun Jaya (stasiun 3). Berdasarkan Peraturan Pemerintah No. 82 Tahun 2001 tentang baku mutu air nilai total fosfat berkisar sebesar 0,2-1 $\mathrm{mg} / \mathrm{l}$. Berdasarkan nilai fosfat yang didapat menyatakan bahwa masih baik untuk dikembangkan kegiatan budidaya system KJA.

Menurut Boyd dalam Effendi (2003), menyatakan fosfor pada perairan alami jarang melebihi $1 \mathrm{mg} / \mathrm{l}$. Tingginya nilai fosfat bisa disebabkan pemanfaatan sungai sebagai MCK oleh masyarakat yang beraktifitas di sekitar sungai dan berasal dari penggunaan pupuk dari aktifitas pertanian dan perkebunan yang berada dekat dengan pinggiran sungai dan diduga terjadi akibat dari akumulasi sisa pakan yang terbuang, feses dan ikan yang mati dari aktifitas budidaya ikan.

Menurut Effendi (2003), fosfat tidak bersifat toksik bagi manusia, hewan dan ikan. Keberadaan fosfat di perairan sangat penting terutama berfungsi dalam pembentukan protein dan metabolisme bagi organisme. Namun tingginya fosfat dikhawatirkan menyebabkan terjadinya eutrofikasi berupa ledakan jumlah Algae (blooming) yang berakibat buruk bagi budidaya. 


\section{KESIMPULAN}

Berdasarkan Hasil penghitungan kesesuaian lahan dengan metode pembobotan menunjukkan kesesuaian lahan yang ada di sungai Komering Desa Serdang Menang kabupaten OKI Sumatera Selatan tergolong dalam kelayakan baik yaitu dengan nilai kelayakan 48. Dari hasil pengukuran parameter kualitas air didapat pH kisaran 6.6 - 6.7, suhu berkisar 24.,53 $26.93^{\circ} \mathrm{C}$, DO 3.93 - $4.36 \mathrm{mg} / \mathrm{l}$, ammonia $0.78-0,16 \mathrm{mg} / \mathrm{l}$, kecerahan perairan berkisar $34.67-43.33 \mathrm{~cm}, \mathrm{CO}_{2} 4.53-5.03$ $\mathrm{mg} / \mathrm{l}$, kedalaman $2.36-2.47 \mathrm{~m}$, kecepatan arus $0.38-0.44 \mathrm{~m} / \mathrm{s}$, nitrat $0.37-0.439$ $\mathrm{mg} / \mathrm{l}$, fosfat $0.009-0.225 \mathrm{mg} / \mathrm{l}$ dan subtrat dasar perairan adalah lumpur.

Pengelolaan perairan sungai komering harus memperhatikan dan menjaga kualitas perairan karena limbah yang dikeluarkan agar tidak mencemari lingkungan.

\section{UCAPAN TERIMA KASIH}

Penulis mengucapkan terima kasih kepada Kementrian RISTEKDIKTI atas dana yang diberikan untuk penelitian ini, KOPERTIS Wilayah II, Rektor Universitas PGRI Palembang, Dekan Fakultas Perikanan, Ketua LPPKMK Universitas PGRI Palembang dan Semua pihak yang telah membantu dalam pelaksanaan kegiatan penelitian ini.

\section{DAFTAR PUSTAKA}

Affan JM. 2012. Identifikasi Lokasi untuk Pengembangan Budidaya Keramba Jaring Apung Berdasarkan Faktor Lingkungan dan Kualitas Air di Perairan Pantai Timur Bangka Tengah. Depik. 1(1): 78-85.

Boyd CE. 1983. Water Quality in warm Water Fish Pond. Auburn University Agricultural. Entertaiment. Auburn

BPS OKI. 2015. Luas wilayah menurut Kecamatan di Kabupaten Ogan
Komering Ilir. Badan Pusat Statistik Kabupaten Ogan Komering Ilir.

Effendi H. 2003. Telaah Kualitas Air bagi Pengelolaan Sumberdaya dan Lingkungan Perairan. Kanisius, Yogyakarta.

Ervinia A. 2011. Keadaan Amonia Pasca Aerasi Hipolimnion di Danau Lido Bogor Jawa Barat. [Skripsi]. Institut Pertanian Bogor, Bogor.

Haris RBK, Nurbambang A, Anggoro S. 2017. Analisis Prospek Pengembangan Usaha Pembesaran Ikan Bandeng (Chanos chanos Forskal 1775) di Kecamatan Tugu Kota Semarang Provinsi Jawa Tengah. Jurnal Ilmiah Agr IBA. 5(1): 70-83

Isnaini A. 2011. Penilaian kualitas air dan kajian potensi situ salam sebagai wisata air di Universitas Indonesia. Jakarta

Peraturan Pemerintah. 2001. Peraturan Pemerintah Republik Indoneria Nomor 82 Tahun 2001. Tentang Pengelolaan Kualitas Air dan Pengendalian Pencemaran Air.

Praptokardyo K, Muskita W. 2008. Pengembangan Perikanan Budidaya. Sekolah Tinggi Perikanan Jurusan Penyuluhan Perikanan. Bogor.

Samuel, Adjie S. 2008. Zonasi, Karakteristik Fisik-Kimia air dan Jenis-jenis ikan yang Tertangkap di Sungai Musi, Sumatera Selatan. Jurnal Ilmu-ilmu Perairan dan Perikanan Indonesia. 15 (1): 41-48.

Sari KY. 2011. Analisis Spasial Citra

Satelit Landsat untuk Penetuan

Lokasi Budidaya Keramba Jaring

Apung Ikan Kerapu di Perairan

Pulau Semujur Kabupaten Bangka Tengah. Institut Pertanian Bogor. Bogor.

Sastrawijaya. 2000. Pencemaran Lingkungan. Cetakan Ke-2. Penerbit PT Rineka Cipta. Jakarta.

Wardoyo STH. 1982. Water Analisys Manual Tropical Aquatic Biology, Bogor. 
Wiadnyana NN, Husnah, Gaffar AK. 2011. Perikanan dan Kondisi Lingkungan Sumberdaya Ikan Perairan Umum Daratan Riau. Balai Penelitian Perikanan Perairan Umum. Pusat
Penelitian dan Konservasi Sumber Daya Ikan. Badan Penelitian dan Pengembangan Kelautan dan Perikanan. Kementrian Kelautan dan Perikanan. 